\title{
Social Change and Identity - Education and the Socio-Political Awareness of Sarawak Malays Before 1963
}

\section{MUHAMMAD KHALILUR RAHMAN BIN TAMAM}

\author{
Faculty of Social Sciences and Humanities, Universiti of Malaysia Sarawak, 94300 Kota Samarahan, Sarawak \\ Malaysia \\ Corresponding author: khalilurtamam@gmail.com
}

\begin{abstract}
Education emancipates a society, and this is also true in Sarawak for where it has an important role in maintaining the core values of Sarawak Malay identity politics. Education, and how it is related to the political consciousness of the Sarawak Malay, shall be the main subject of this research. The purpose of this study is to analyse the role and importance of education in maintaining the core values in Sarawak Malays identity politics. This study was conducted through library research and other secondary sources as it tries to explore the elements of education and the social and political change of the Sarawak Malays. Education not only provided the access to social mobility and socio-political awareness of the Sarawak Malays, but it also enhanced the politics of identity of Sarawak Malays through the inculcation of values based on Islam and the local context of Malayness (Kemelayuaan).
\end{abstract}

Keywords: Education, Malay, political awareness, Sarawak, social change

Copyright: This is an open access article distributed under the terms of the CC-BY-NC-SA (Creative Commons Attribution-NonCommercial-Share Alike 4.0 International License) which permits unrestricted use, distribution, and reproduction in any medium, for non-commercial purposes, provided the original work of the author(s) is properly cited.

\section{INTRODUCTION}

In the past two decades, Francis Fukuyama gloriously declared the end of history with the victory of liberal democracy. However, the victories of liberal democracy order at stake with the rise of identity politics. Identity politics can be described as the people adopting political positions that are based on their ethnicity, race, sexuality or religion (Heath \& Richards, 2018). This view differs from the notions of 'New Politics', which focuses on justices and equality in terms of socioeconomics conditions, participatory politics and transition from consociation to deliberative democracy.

However, development in politics has caused the crisis on the meaning of identity, when the idea of identity that was built around self-esteem, based on the historical experiences and social contexts, were undervalued by the liberal democratic ideas, thus reduced them to social identification that is based on economic status and material (The Economist, 2018). The feeling of a sense of belonging according to the nation-state's boundary has pushed their resentment and fought for recognition of their undervalued identity.

Politics of identity were in fact a very recent subject of study as it comes into view during the period of 1980s and 1990s in the discourse of cultural politics. Despite being not widely discussed, politics of identity as a phenomenon was prevalent during the post-colonial period, when many of the colonies of Great Britain seek independence after World War 2 (WW2). This was also true in post-WW2 Sarawak.

In the aftermath of the war, the last Rajah of Sarawak, Charles Vyner Brooke decided to cede to the British Empire as a colony of Britain in 1946. The cession of Sarawak to the British Empire was done for several reasons. Firstly, the internal dispute between the Brooke's family on the ascension to the throne (Said, 1975) and secondly, the estranged relationship between Britain and Sarawak. Sarawak was not formally a colony of Britain as it was 
governed by the Brooke family (Ho, 2001). The third factor was the declining socioeconomic of Sarawak that worsened by WW2 (Yaacob, 2014).

The nationalist response was to be expected as the decision to cede Sarawak to Britain conflicted with the 1941 constitution that promised self-governance by the natives. Many anti-cession movements were initiated to show rejection of the cession move by the Brooke's government. Persatuan Kebangsaan Melayu Sarawak (PKMS) was one of the main anti-cession movements in Kuching. PKMS mobilised many of its members to protest the cession of Sarawak.

The various issues that are plaguing the Sarawak Malay community had ignited the torch of nationalism among the Sarawak Malays. Experience of colonization by the Brooke Dynasty and the passive attitude of the Malay elites have caused resentment among the commoners. These issues were later brought up by the later generation of educated Malays to voice and fight for their rights and interest in the state.

\section{Identity politics and ethnicity}

Identity politics can be defined as a tendency for a group of people of a religious belief, ethnicity or social background to form exclusive political alliances, moving away from the traditional broad-based party politics. Its political activity and theory are based on the injustice that is faced by members of certain social groups. They want to claim the distinctiveness of their groups and challenge the dominant characterization that oppressed them (Heyes, 2020).

Fukuyama (2019) relates identity with dignity. The dignity that is trampled on only invites resentment of related groups. The humiliation of related groups motivates them to demand recognition or reinstitute their dignities carries more emotional values than the pursuit of economy.

Identity such as ethnicity can be one of the potent forces for political mobilization as the people are asserting their belongingness to the states to claim the material resources and political positions. In the discourses of identity politics, it is always asserted that identity politics was used by the weak and minority ethnics of a certain polity or community in asserting their rights. However, the role of identity politics in the preservation of political power by the ethnic of the majority is always left out of examination.

Three perspectives can be taken in analysing the views and role of ethnicity in identity politics. First, the way ethnicity is conceptualized by scholars and commoners. The ethnic characterisation can be referred to any, or a combination of the geographic region the ethnic origins, their language and dialect, culture, economic or social positions. Secondly, the special place that certain ethnicity has in the formation of the modern nation-states. Etienne Balibar (1991), as cited in Leach, Brown, \& Worden, 2008) argued that modern nations were a result of different people coming together to be part of a fictional identity that identifies them as a group. Third, the subjectivity of the reality of the ethnic's identification and the benefits (Leach et al., 2008). The idea of identity continues to resonate with the people as it provides the sense of self-esteem, social status, supplies existential security and knowledge and granting social protection.

\section{The core identity of the Sarawak Malays}

Malayness is considered a core identity for the Sarawak Malays. Hence, what determines or constitutes Malayness (Kemelayuan)? On what basis did the Sarawak Malays assert their identity and their history in Sarawak? There were several theories that arise in discussing the origins, identity, and the ideas of Malayness of Sarawak Malays.

James Brooke defines the Sarawak Malays as "all coastal, sea-faring Moslems in the archipelago" (Babcock, 1974 as cited in Amir, 2015). Prominent Sarawak historian Datu Dr. Sanib Said (2010) suggests two 
opinions on the origins of the Sarawak Malays: either they were originated from the other part of the Malay Archipelago or they are a derivation from the natives of Sarawak itself.

The first opinion suggests the origins of the Sarawak Malays come from the descendant of the Sumatera princes and nobles that come to Sarawak. Local literature such as Hikayat Datu Merpati and Syair Tarsilah Abang Gudam suggest the Malays of Kuching were descendants of Datu Merpati while the Malays of Saribas were descendants of Abang Gudam.

The second opinion suggests that the Malays of Sarawak were originated from the Islamised natives of Sarawak itself. This phenomenon of 'masuk Melayu' or entering Malayness was common among the Iban, Bidayuh, Melanau and other minority groups since the $15^{\text {th }}$ century. Not only they professed Islam, but their sociocultural practices also changed as a result of the accommodation, acculturation, assimilation, and amalgamation processes.

Due to the complex origins of the Sarawak Malays, one might suggest that it was Islam that unified the meaning to become Malay in Sarawak. Islamization of the local community during the reign of the Brunei Sultanate at the northern part has shown many of the Muslim 'rakyat' (citizens) were in fact converts from local Dayak groups (Brown, 1973 \& Leake, 1990, as cited in Milner, 2011). Leigh (1974) also mentioned that the Melanaus and Kayans were also grouped into Malays because of Islam. Three-quarters of the Melanaus became Muslim by 1960 and described themselves as 'Malay'. This shows how important is Islam in defining the Malays. Tom Harrisson (1970) also commented that the non-Malays would be surprised to learn that the present Malay population was derived from the local Sarawak natives.

\section{Sarawak Malays in politics - from Brooke's rule to the British colony}

The Sarawak Malays maintain their political dominance in a state where they were not the majority. Despite coming second after the Iban in terms of population, the Sarawak Malays have maintained their political dominance over Sarawak for decades before the cession of Sarawak to the British. This dominance was challenged several times and threatened by the split between the Sarawak Malays - especially during the Cession of Sarawak to Britain in 1946, and during the inclusion of Sarawak into the Federation of Malaysia in 1963.

Even though historically Sarawak was a state or 'kerajaan' in the sense of Malay concept of polity under the Brunei Sultanate, the Sarawak Malays lost their political rights and control over their territory due to the adoption of European-style administration during the rule of Brooke's Dynasty (Said, 2010). Their influence further eroded as administration of the states was gradually replaced by the European administrator, and the traditional Malay leaders among the Perabangan were reduced to mere figurehead and functions only for ceremonial purposes. They eventually lost the decision-making power in the newly established Council Negeri after the secession of Sarawak to Britain in 1946.

During the post-cession period, Sarawak Malays experienced economic, social, and political decline. The Malay leaders among the Perabangan aristocrats were ineffective and failed to respond to the issues which have become the prelude to the rise of a new Malays intelligentsia. This is evident during the anti-cession movement when the leaders were among the Malay intelligentsia while the pro-cession was among the aristocrat Malays. During the first Malay split in 1946 due to the cession controversy, we see the transition of political leadership from the traditionally-inherited legitimacy to charismatic-educated legitimacy. The Malays no longer see the traditional leaders as the protector of their rights and see the educated intelligentsia as their new protector. This has brought upon multiple political organisations from both sides such as Persatuan Melayu Sarawak (later, Persatuan Kebangsaan Melayu Sarawak), Persatuan Melayu Sibu (PMS) and Barisan Pemuda Sarawak that sided with the Anti-Cession movement, while Young Malay Association (YMA) on the Pro-Cession side. The Cession 
Controversy also has brought further resistance from the Malays such as the Rukun 13 group that planned the assassination of Duncan George Stewart, the second governor of colonial Sarawak.

The transfer of power from the Brooke Dynasty to the colonial government was an eclipse of the Sarawak Malay political power and influence. The Malay community was already divided due to the differing opinion on the cession of Sarawak to Britain. At the heat of the Anti-Cession movement, in April 1947, 338 public servants, with 76 of them teachers, resigned from the administration (Ooi, 2001). This response was due to the Circular No. 9 issued by the colonial government that demanded absolute loyalty from the civil servant. The circular also warned any public servant not to get involved in the Anti-Cession movement otherwise any public servant will face immediate dismissal (Sanib, 2010).

The modernisation of administration during the rule of the Colonial Office was responsible for the erosion of the political power of Sarawak Malay, especially the Malay Aristocrats. In the new administration of the colonial government, the British imported European expatriates to accommodate the needs for qualified officers. The position in the Senior Service was mostly consisted of the expatriates, while the Native Officers were only assigned to help with the duty of the District Officers (Yaacob, 2014). At the municipal/local council level, the Sarawak Malay political power further trimmed down as not many of the Malays were elected to the local council. As a matter of fact, during the first local government election for Kuching Municipal Council, only six of the Malays candidates won while there are 21 Chinese candidates won.

Yaacob (2014) argued that even though the British proposed to have more ethnic composition in the government, the three-tier system introduced by the colonial office only made the results more racially divided. The people of different ethnicities tend to vote for their respective ethnic groups. This gave the edges for the ethnic group with the biggest populace such as the Chinese and Iban compared to the Malays.

Taking lessons from the past, the Malay leaders learned to compromise to maintain the unity among the Malay-Muslim community to avoid splits that will further compromise the Malays rights as one the indigenous people of Sarawak and the interest of the Muslim in the state.

\section{Political and social change through education}

Philosophically speaking, Albert Einstein (as cited in Ujang, 2011) defined education as “...what remains after one has forgotten what one learned at school". Meanwhile, a local Malaysian scholar, Syed Muhammad Naquib alAttas (1980) viewed education as "...recognition and acknowledgement of the proper places of things in the existence".

Education does not only function to transmit knowledge and values. It also can be a major factor in political, social, and economic change. Education is perceived as the instrumental elements in bringing social change into society. Since the time of antiquity, Plato and Aristotle affirmed and recognised the place that education has in political development: "What you want in the State, you must put into the School".

Dewey (1922), recognising the role of education as an important institution in improving the social condition mentioned that, "as society became more enlightened it realised that it was responsible not to transmit and conserve the whole of its existing achievement but to strive for a better future society".

Education is a necessary element in bringing change within society. Education is also important as it reminds the people of their origin, history and thought that their civilisation is built upon, which characterises identity politics. Furthermore, being knowledgeable is important as it helps the people to discern truth from falsehood as it provides the people with the tools to make a rational decision and to act towards change. 


\section{METHODOLOGY AND SOURCE}

This research tried to explore the importance of education that helps in establishing the political identity of the Sarawak Malays. Therefore, this study was exploratory in nature as it seeks to investigate and further clarify the concepts that are involved in the phenomena being studied.

This research covered the Sarawak Malay community between the period of 1946 to 1963 . The approach was done through qualitative method and data collection was done through library research and other secondary sources to take account of the records and opinion of the past.

\section{MAIN THEMES AND DISCUSSION}

The data collected and analysed from primary and secondary sources point to a number of themes that affect the important role of education in Malay Identity politics during the period. The themes are Brooke's policies, formal education and political awareness, and are discussed further in this section.

\section{The Brooke's views on education of the Malays}

Education can be a means to achieve status in society. This was true in the sense where to become educated means to have more options in choosing a career. During the Brooke Dynasty, joining the 'perentah' or the administration meant social mobility. This has brought demand for more government schools to be open for the locals.

The Brooke's saw the Malay aristocrats as a group of people that have the nature to administer the people of Sarawak (Ooi, 2001). For that reason, James Brooke maintained and adopted the traditional ruling class to help him in his administration. However, the Rajahs did not favour the Malays to be more educated. Ooi (2001) also mentioned that the Brooke Rajahs envisioned the Malays to maintain their 'traditional' way of life and want them to be educated with practical education such as agriculture and health education. James Brooke argued that the western education will 'corrupt' the mind of the natives while Charles and Charles Vyner Brooke both thought the Malays had to be encouraged to become farmers after finishing their primary education.

However, one might argue that what the Brookes feared the most was the political implication resulting from the emancipation of natives through education. Charles Brooke (1866) correlated education as the main factor for a revolution to arise. If the natives were educated, they can be fearsome opponents and bring disaster against the colonial rule (Ooi, 2001).

\section{Early Sarawak Malays response towards formal education}

To secure the support from the Malay traditional leaders, James Brooke promised that he will not interfere with Islamic affairs and Malay customs. However, despite being the biggest benefactor of the Brooke's policies, the benefits were not evenly distributed among the Sarawak Malay community. The responses were divided among the elites, the middle class, and the commoners.

According to Leach (as cited in Osman, 1990), the Malay groups that benefited the most during Brooke Dynasty rule was the Perabangan elites, the Tuanku and the middle class that come from the Malay and English educated, which also known as 'orang kerani' (the clerk men). For them, being educated implied being able to get a job with the Brooke's administration. Ooi (2001) mentioned that being appointed into the position of Native Officer or Head of Village during the Brooke's administration signified power and prestige. Being appointed into that position also meant being closer to the White Rajah. Those that were appointed into that position have the basic education in the Malay language and so that they able to exercise their official task. 
The middle class correlated education with social mobility. Being educated in an English medium school and getting the English education certification enabled them to apply for positions in the Brooke's administration. In contrast to the Perabangan and the Tuanku elites, just having 'Abang' and 'Tuanku' in their names was enough to secure the opportunity to work with the government due to their privilege as part of the aristocratic class within the Malay society. However, the middle class and the commoners have to struggle to secure the positions (Ooi, 2001).

As for the Malays of the lower class, they considered education as unimportant. The parents among the farmers and the fishermen considered the time spent at school by their children were a loss of free labour for them (Ooi, 2001). They questioned the need for being educated when in the end, the graduates who were unable to find work went back to the village and become farmers like their parents (Harrisson, 1970).

\section{Education and Social Mobility}

The lenient policies since the time of James Brooke had given them the illusion of peace and made them perceived that Sarawak was not a colony or was being oppressed by the Brooke Dynasty. According to Osman (1990), the Malays generally were given privileges and have special places within the Brooke administration, even though it was monopolised by the Perabangan and Tuanku elites.

Education, besides functioning to transmit knowledge and values, can be used to initiate social change. In the context of Sarawak Malays, it can be seen from two perspectives. First, is to move upward in the economic and social ladder; and second, is to initiate change in the society.

Education can improve the economic status of the individual and initiate social change within the society. During the Brooke's rule, those serving as white-collar workers promised status and a better life. The only way for a commoner to achieve this is through education. The middle-class Malay considered education as important because of its usefulness in social mobility, compared to the elites such as the Perabangan, as they have already secured positions in the administration based on their birth right (Ooi, 2001). However, for the middle class, they can only achieve it through merits, which come from education. It is through education that, the students from lower-income group can climb up the social ladder, increase their social mobility and be a part of a higher economic class.

The development of Malay education since the Brooke Dynasty until before the Japanese Occupation has made the Malays involved more in education. The opening of Malay schools and higher education institutions implied that education was no longer exclusive among the elites as more Malay commoners became capable and had opportunity to study in the government-sponsored schools and institutes. Somehow, the Malays have regained their consciousness that they have been deprived of political and economic position in Sarawak especially during the 1941-1945 Japanese Occupation. This consciousness is most apparent among the non-Perabangan Malays.

\section{Education as an agent of social change and political awareness}

Osman (1990) noted how education was changing the attitude and mentality of the Malay in the later decades, especially during the Cession of Sarawak in 1946 where the education received by early generation of Sarawak Malays has contributed to the rise of the Malay intelligentsia. This rise came from the educated and professional Malays such as teachers and government officers who were mostly graduates from the Malay and English medium school.

These educated Sarawak Malays also initiated publication to spread awareness among the peoples of Sarawak such as the publication of Fajar Sarawak, the first Malay newspaper in Sarawak with the motto:

"Fajar telah menyinsing, bangunlah wahai anak bangsaku". [The dawn has come, rise my brethren.]

(Osman, 1990) 
Haji Mohd Daud Abd Ghani, Mohd Awi Awang, Mohd Johari Anang, and H. K. Abd Rahman were the educated Malays and non-Perabangan who wrote based on nationalist themes in local newspapers. The editor in chief was none other than Rakawi Mohd Yusof, who was well known for his books, Hikayat Sarawak and Melati Sarawak, published in the early 1930s. In the first issue of Fajar Sarawak on 1st February 1930, Rakawi (1930) emphasized the importance of education among the Sarawak Malays and he called the Sarawak Malays to support each other, either financially or through education. He also called all educated Malays to educate the people in order to bring progress (kemajuan) to society.

Other newspaper publications, such as Utusan Sarawak, also propagated the importance of education for social change. Utusan Sarawak was founded by Ikhwan Zaini, Johari Anand, and their comrades from Angkatan Semangat Anak Negeri Sarawak (ASAS). Its slogan, "Oleh Ra'yat Untuk Ra'yat" (By people, for people), sought to establish itself as a medium for exchanging ideas and critics.

Achie (2001) stated that Utusan Sarawak emphasized two aspects on the issues of education: first, the importance of education and knowledge, and second, the problems and the future of the Malay education. Utusan Sarawak considered education and knowledge important as it is the pillar for progress.

Finally, on initiating change in the society, the early Sarawak Malay intelligentsia, like Rakawi Muhammad Yusuf and Ikhwan Zaini, had always emphasised and propagated on the importance of education among the populace through their newspaper. They criticised the impoverished conditions of the Sarawak Malays of their time hence the call for Malay elites to support the awakening by giving financial aid for the poor Malays to pursue their studies. Here we observed that the educated Malays become an agent for social change by spreading the importance of education among the local populace and called for an awakening to their situation for the betterment of society.

\section{Monopoly of education to maintain the status quo}

During the Brooke's rule, the policies on the education of the Malay were restricted. First, not many of the Malays were encouraged to pursue their studies at a higher level as the Brooke's consider this as unnecessary for them compared to their practical knowledge of farming. The policies on the education of the Malays were primarily focused on how to be better farmers than their parents, but not to focus on social mobility. However, according to Osman (1990), Sarawakians were acting passively toward the colonial master. They perceived the Brooke Dynasty as benevolent and treat them in a special manner.

The policies such as giving the Malays autonomy in cultural and religious affairs have the effect of increasing local trust towards the Brooke Dynasty. They did not think of the Brooke as an outsider who is to colonise them. Paulo Freire (1972), through his book, Pedagogy of the Oppressed once mentioned this phenomenon. The oppressor needs to show and express their generosity toward the oppressed at the same time perpetuate injustice itself in the social order.

Contextualising this in Sarawak during the Brooke's rule, the ruling class perpetuated the injustice by maintaining the status quo of the Sarawak Malays at that time: by giving Malay elites favour in return for their loyalty to the Brooke government and to avoid education that would make the Malay peasants politically conscious. As critical consciousness awakens, the oppressed will express the social discontents as discontents are the reality of the oppressive situation (Freire, 1972). If the Malay peasants are ever awake, that would spell the doom of the Brooke Dynasty and may give way to a reality of the second Malay Plot.

\section{Islam as part of Sarawak Malay identity}

Abdul Rahman Rukaini (1979) stated that the spread of Islam to Sarawak had changed the worldview or weltanschauung of the Malays and natives. The Islam that is deeply embedded in the Malay worldview is that 
becoming a Muslim is often associated with 'masuk Melayu' (entering Malayness) (Yaacob, 2014). Islam has influenced their language and culture, that which also attracted other natives to profess Islam.

Since the rule of the Datus and nobles under Brunei's Sultanate, the traditional informal religious education was already flourishing. The informal-traditional Islamic education prepared the Malay individual with the necessary knowledge, especially on reading the holy book (al-Quran) and reading the jawi scripts, which also meant the ability to read and write. Ooi (2001) mentioned that the Malay elites' families highly regard religious education, and failure to inculcate religious studies among their children is a humiliation for them.

The Malay-Muslim community was agitated with the establishment of missionary schools, which was supported by James Brooke (Yaacob, 2014). However, Ooi (2001) mentioned that James and Charles Brooke did guarantee that the Christian missionary will not interfere or propagate Christianity among the Malays. Acknowledging the importance of formal education for the Malays, many Malay schools were established. Early Malays schools such as Sekolah Abang Kasim (later known as Sekolah Kampung Jawa) and Sekolah Kampung Gersik have focused on the teaching of Quran reading, read and write Jawi script, arithmetic, geography, and history (Said, 2010). Occasionally, the English language was also taught by the visiting Anglican missionary.

Besides schools, credible ulama (Islamic scholars) were considered important to deepen the knowledge and appreciation of Islam (Drahim \& Mat Zain, 2017) as far as the Malays are concerned. However, there are very few writings of Islamic scholars from Sarawak beside Shaykh Uthman al-Sarawaqi. He was considered one of the great scholars of Islam and his students later became the pioneer in the awakening of Sarawak nationalism (Saleh, 2018). One of his students was Datu Patinggi Abang Haji Abdillah. He was mentioned as one of the local Islamic scholars that cooperated with Datu Hakim Imam Haji Morshidi to establish the Sekolah Kajang Wanita in order to provide access to education for women (Abd Rahman, 1992).

\section{The colonial government policies on education and the criticism}

Ooi (2001) mentioned the colonial government policies in education were based on two objectives i.e. to close the gap of education between the natives and the Chinese, and to establish a national education system. All of these are needed to foster a common Sarawak identity. The mass resignation of the public servants in April 1947 had crippled the education department as 87 of the 152 Malay teachers and all the 56 training teachers resigned. This has caused 22 of the 62 Malay schools and the Batu Lintang Teachers Training College to close. Some of them tried to mitigate the effect with the Sekolah Ra'yat (People's School) initiatives however, the efforts were insufficient to fill the vacancies left by the closure of government schools.

One of the earliest policies initiated by the colonial government was the introduction of the local council school system. This system focuses on the ability to read, write, and count at the primary stage (Yaacob, 2014). The students were taught in their respective mother tongue. In the post-primary stage, they were chosen to continue their study in either the secondary, vocational, or technical school. The government also used the self-help strategy to encourage the local community to contribute positively to education. This strategy was introduced to relieve the financial constraints of the local council to maintain and operate the schools (Ooi, 2001). More extensive policies on education were the opening of the Training Centre and School, Batu Lintang in 1948 and the introduction of Grant Code (Regulations) in 1956.

In envisioning the national education system for Sarawak, the colonial government introduced English as the medium of instruction, and the government saw that this was accepted by most of the citizens. The English language was perceived as the language of education and economy and to potentially give its learners better opportunity to continue their study and to get better jobs (Ooi, 2001). The conversion to English as the medium of instruction also marked the gradual closure of the communal education on the secondary level, especially the 
Chinese vernacular schools. Ooi (2001) also noted that the government introduced a new syllabus, Sarawak-based textbooks and examination to accommodate the changes in the medium of instruction and standardization of syllabus in schools.

In spite of the improvement done by the colonial government, not all new policies were accepted by the Sarawak Malays and the benefits were unevenly distributed. The Malays through their intelligentsia and leaders voiced the need for more schools for the Malays and introduced the religious subject in the syllabus (Yaacob, 2014). The Malays of Miri as such once demanded the Miri City Board for a Malay secondary school, while Haji Suut Tahir from Kuching Municipal Council expressed the need for Islamic lesson to be made compulsory for Muslim students. The Malays saw the advancement of Christian education as worrying and the Malays in general still distrust and wary of the missionary school.

Despite the government initiatives to establish a national education system for Sarawak, the education system in Sarawak is still divided between ethnic groups. This was pointed out by Haji Suut Tahir in the Council Negri (Utusan Sarawak, 1958 as cited in Yaacob, 2014). On 23 December 1959, Utusan Sarawak also published an article that criticised the uneven distribution of grants under Grant Code 1956 that benefits the non-native the most. Yaacob (2014), citing from Utusan Sarawak, mentioned, the expenditure for a Chinese was $\$ 19.30, \$ 5.80$ for a Malay, and $\$ 1.18$ for a Dayak. The Education Director, M. G. Dickson tried to brush off criticism by arguing that the biggest demand for the grant came from the Chinese School as they knew when to take the chance. However, Yaacob (2014) argued that, contrary to the Chinese, the Malays did not have any private school, while the Sekolah $R a$ 'yat were small in number and most of the Malay Schools were under the administration of the local council, thus at a disadvantage, compared to the well-established Chinese school.

\section{The Sarawak Malay politics of identity and education}

As earlier discussed, education has a fair share in bringing political awareness among the Sarawak Malay populace. Education plays its role, not only as part of the instrument in the transmission of knowledge and values, but it also provides the means for uplifting the socioeconomic conditions of the Sarawak Malay. The disadvantages experienced by the Sarawak Malays also gave awareness to uplift their position and compete with other ethnic groups even though their responses toward education and its significance toward their life may differ from one another.

Being one of the many ethnic groups in Sarawak, to maintain the identity of the Malay is to maintain their religion that is Islam. The education centres and institutions claimed crucial in inculcating the knowledge and values of Islam were considered an important part in maintaining Malay identity. Despite being under the rule of the Brookes, this researcher discovered that Islamic education among the Sarawak Malays was well maintained throughout history and being a part of the factors that initiated the social change of Sarawak Malays.

The researcher opined that it was a blessing in disguise that Sarawak was fated to be part of the Malaysian federation. The Sarawak Malay can benefit from the education system where there is an emphasis on Islamic studies, thus enabling them to fill in the gap that was left by the informal Islamic education of Sarawak by accommodating the changing demography of the Sarawak Malay today. The education system and syllabus enable them to be educated and have knowledge of Islam, compared to their parents that neither have the luxury nor access to education.

The political awareness among the Sarawak Malay may never arise if not for the early generation of Malay intelligentsia that fought through the pen to awake their brethren. The education that they obtained enable them to think critically and express their ideas in order to see that the Malays of Sarawak have liberated their minds from the oppressed and siege mentality that resulted from the long colonisation they experienced. The politics of identity of the Sarawak Malay, nevertheless, is driven by education where it enables critical thinking and the rise of 
consciousness on thinking and reflecting about the fate of a people's nation. As Freire (1972) said, “...reflection true reflection - lead to action".

\section{CONCLUSION}

This study has explored the narratives on education in the past through qualitative method by reviewing available literature and primary and secondary sources related to this study. Education has greatly contributed to the development of the Sarawak Malays' social and political awareness. The struggles of the Malay aristocrats using their political positions and influence to bring education to the Malay populace and the struggles of the new generation of educated Malays by raising awareness through the newspaper have been timeless struggles. Although education was monopolised by the aristocratic families and so goes the restriction of the Brooke policies, in the earlier stage of colonisation, the Malays and their leaders did in fact manage to expand access to education to the wider Malay populace. This allowed the Malays to rise upward the social ladder where new opportunities were open for them. This also allowed the rise of nationalist and educated Malays at the end of Brooke's rule in Sarawak.

The researcher found several interesting findings to be explored more in the future. On the role of education as a medium to inculcate the Malay and Islam identity, it was thanks to the education, either the informal education in the past or the formal Islamic study of today that it manages, at the very least path, the way for the institutionalisation of Islamic instruction alongside the broader secular education to the Sarawak Malay.

As an agent of social change, education proved to be a potent element to bring about awareness and political consciousness of the masses, as what we observed here in Sarawak. However, in the long run, the effect may vary depending on the extent to which the current Sarawak Malays perceive education to be. A more comprehensive study on the development of Sarawak education post-Malaysia 1963 may bring new perspectives on the social change of the Sarawak Malays and their politics of identity.

\section{REFERENCES}

Abd Rahman, I. (1992). Pendidikan Islam Malaysia. Bangi: Penerbit UKM.

Achie, N. (2001). Kemunduran Pendidikan Masyarakat Melayu di Sarawak Pada Awal Pemerintahan Kolonial British 1946-1950: Satu Tinjauan Dari Perspektif Utusan Sarawak 1949-1950. Malaysia Dari Segi Sejarah, 29(2001), pp. 8-30.

Amir, J. (2015). Asal usul Melayu Sarawak: Menjejaki titik tak pasti. Melayu: Jurnal Antarabangsa Dunia Melayu, $8(1), 1-17$

Brooke, C. (1866). Ten Years in Sarawak. London: Tinsley Bros.

Dewey, J. (1922). Democracy and Education: An Introduction to the Philosophy of Education. New York: Macmillan.

Drahim, N. A., \& Mat Zain, F. (2017). Biografi Datu Patinggi Abang Haji Abdillah: Tokoh Nasionalisme Negeri Sarawak. Prosiding Nadwah Ulama Nusantara (NUN) VII: Ulama dan Pemikiran Wasatiyyah Nusantara (pp. 215-221). Bangi: Universiti Kebangsaan Malaysia.

Freire, P. (1972). Pedagogy of the Oppressed. London: Penguin Books.

Fukuyama, F. (2019). Identity: The Demand for Dignity and the Politics of Resentment. New York: Picador.

Harrisson, T. (1970). The Malays of South-West Sarawak before Malaysia: A Socio-Ecological Survey. London: Macmillan.

Heath, A., \& Richards, L. (2018). Nationalism, racism, and identity: what connects Englishness to a preference for hard Brexit? Retrieved October 29, 2020, from British Politics and Policy at LSE: http://blogs.lse.ac.uk/ politicsandpolicy/englishness-racism-brexit/

Heyes, C. (2020). Identity Politics, Fall 2020. Retrieved October 30, 2020, from Stanford Encyclopedia of Philosophy: https://plato.stanford.edu/entries/identity-politics/\#Bib

Ho, H. L. (2001). Penyerahan Sarawak Kepada Kerajaan British, 1946 - 1951. Malaysia Dari Segi Sejarah, 29(2001), pp. 43-73. 
Leach, C. W., Brown, L. M., \& Worden, R. E. (2008). Ethnicity and Identity Politics. (L. Kurtz, Ed.) Encyclopedia of Violence, Peace, \& Conflict, 1, pp. 758-768.

Leigh, M. B. (1974). The Rising Moon: Political Change in Sarawak. Sydney: Sydney University Press.

Milner, A. C. (2011). The Malays. West Sussex: Wiler-Blackwell.

Ooi, K. (2001). Dunia Di Seberang Sungai: Pendidikan di Sarawak Dari Zaman Pemerintahan Brooke Hingga ke Pentadbiran Pejabat Tanah Jajahan. Pulau Pinang: Penerbit Universiti Sains Malaysia.

Osman, S (1990). Perkembangan Pelajaran Bumiputera Sarawak (1841 - 1941). Kuala Lumpur: Dewan Bahasa dan Pustaka.

Rakawi, M. R. (1930). Ucapan Penerbit. Fajar Sarawak, p. 2.

Rukaini, A. R. (1979). Nota Ringkas Mengenai Islam di Alam Melayu. Monograf Persatuan Sejarah Malaysia, 192.

Said, S. (1975). Anti-Cession Movement 1946 to 1951: The Birth of Nationalism in Sarawak. Graduation Exercise, Universiti Malaya, Jabatan Sejarah.

Said, S. (2010). Malay Politics in Sarawak 1946-1966: The Search for Unity and Political Ascendancy. Kota Samarahan: Universiti Malaysia Sarawak.

Saleh, F. (2018). Pengenalan Ringkas Shaykh Uthman Sarawak. In S. M. Z. A. Shaykh 'Uthman Al-Sarawaqi, Nahafat al-Ridwan: Riwayat Hidup Shaykh Uthman Sarawak (pp. 12-38). Kuala Lumpur: Angkatan Belia Islam Malaysia.

Naquib al-Attas, S. M. (1980). The Concept of Education in Islam. Kuala Lumpur: International Institute of Islamic Thought and Civilization (ISTAC).

The Economist (2018). Find out what it means to me - Francis Fukuyama and Kwame Anthony Appiah take on identity politics. Retrieved October 21, 2020, from The Economist: https://www.economist.com/books-andarts/2018/08/23/francis-fukuyama-and-kwame-anthony-appiah-take-on-identity-politics

Ujang. Z. (2011). Embracing the Knowledge Culture; Understanding Knowledge, Putting It Into Practice. Kuala Lumpur: Institut Terjemahan Negara Malaysia.

Yaacob, H. F. (2014). Kedudukan orang Melayu di bawah penjajahan British (1946-1963). Kuala Lumpur: Dewan Bahasa dan Pustaka. 